УДК 620.92

\title{
АНАЛІЗ ЕНЕРГЕТИЧНИХ СТРАТЕГІЙ КРАЇН ЄС ТА СВІТУ І РОЛІ В НИХ ВІДНОВЛЮВАНИХ ДЖЕРЕЛ ЕНЕРГІЇ. ЧАСТИНА 2
}

\author{
Гелетуха Г.Г., канд. тех. наук, Желєзна Т.А., канд. тех. наук, Баштовий А.І., канд. тех. наук \\ Інститут технічної теплофізики НАН Украӥни, вул. Желябова, 2а, Київ, 03680, Україна
}

\begin{abstract}
Розглянуто поточний стан та перспективи розвитку відновлюваної енергетики в світі та в Європейському Союзі. Проаналізовано існуючі енергетичні стратегії та прогнози розвитку енергетики до 2050 року. Показано необхідність скорочення загального споживання первинної енергії за рахунок широкого впровадження енергоефективних технологій та енергоощадних заходів.
\end{abstract}

Рассмотрено современное состояние и перспективы развития возобновляемой энергетики в мире и в Европейском Союзе. Проанализированы существующие энергетические стратегии и прогнозы развития энергетики до 2050 года. Показана необходимость сокращения общего потребления первичной энергии за счет широко внедрения энергоэффективных технологий и энергосберегающих мер.

Бібл. 10, табл. 3.

Ключові слова: відновлювані джерела енергії, відновлювана енергетика, кінцеве енергоспоживання, енергоефективність, парникові гази.

АЕС - атомна електростанція;

ВВП - валовий внутрішній продукт;

ВДЕ - відновлювані джерела енергії;

ВЕС - вітрова електростанція;

ВКЕ - валове кінцеве енергоспоживання;

ГЕС - гідроелектростанція;

ЖКГ - житлово-комунальне господарство;

ЗППЕ - загальне постачання первинної енергї;

НЕC - Нова Енергетична стратегія;

НПДВЕ - Національний план дій з відновлюваної

\section{Енергетичні стратегії деяких країн Європейського Союзу та свіму}

\section{Данія}

У 2011 році в Данії було прийнято Енергетичну стратегію до 2050 року [1], яка окреслила заходи для досягнення довгострокової мети - повної незалежності країни від викопних палив. Стратегія також визначає нові коротко- та середньострокові заходи для виконан- енергетики;

ОЕСР - Організація економічного співробітництва та розвитку;

ПЕР - первинні енергоресурси;

СЕС - сонячна електростанція;

н.е. - нафтовий еквівалент;

у.п. - умовне паливо.

\section{Нижній індекс:}

е - еквівалент.

ня національних цілей 2020 року - 33 \% ВДЕ у валовому кінцевому енергоспоживанні (що навіть перевищує офіційну ціль Данії як члена СС $30 \%$ ), 10 \% ВДЕ на транспорті та скорочення загального енергоспоживання на $6 \%$ у порівнянні з 2009 p.

Данія поставила собі за мету увійти до першої трійки країн світу з точки зору успішності впровадження відновлюваних джерел енергії до 2020 року та стати однією з найбільш енергоефек- 
тивних країн-членів ОЕСР також до 2020 року. Існуючі тенденції свідчать, що країна динамічно рухається у напрямку успішного виконання своїх коротко- та довгострокових цілей в секторі енергетики.

\section{Австрія}

Відновлювані джерела енергії наразі займають друге місце в структурі енергоспоживання Австрії (30\%) після нафтопродуктів (36 \%). 3 усіх ВДЕ 58 \% припадає на біомасу та органічні відходи. Енергетична стратегія Австрії до 2020 року ставить за мету збільшення частки ВДЕ у валовому кінцевому енергоспоживанні до 34 \%. При цьому важливу роль відіграє впровадження заходів з енергоефективності та енергозбереження, оскільки завдяки цьому планується втримати ВКЕ у період до 2020 р. на рівні 2005 р. (близько 1150 ПДж/рік). Без застосування заходів 3 енергоефективності валове кінцеве енергоспоживання країни у 2020 р. могло б збільшитися на 200 ПДж/рік.

Наразі в Австрії на громадському та урядовому рівнях йдуть дебати щодо необхідності прийняття нової стратегії з більшими часовими рамками та амбіційнішими планами. Асоціація відновлюваної енергетики Австрії пропонує прийняти нову енергетичну стратегію принаймні до 2030 року з такими ключовими цілями: скорочення кінцевого енергоспоживання на 940 ПДж порівняно з 1990 роком, нарощування частки відновлюваної енергії до $60 \%$ та скорочення викидів парникових газів на $60 \%$ до 2030 року [2].

Також існують прогнози інших фахових організацій. Згідно оцінок Австрійського енергетичного агентства, у 2050 році країна може повністю задовольнити кінцеве енергоспоживання (близько 650 ПДж/рік) за рахунок ВДЕ. При цьому загальний обсяг споживання енергії має зменшитись від рівня 2020 року на 500 ПДж/рік за рахунок впровадження енергоефективних та енергоощадних технологій й заходів. Планується знижувати ВКЕ на 1,5 \% у рік у період до 2050 p. і збільшувати частку ВДЕ на $3 \%$ у рік до 2030 р.

Треба зазначити, що вже зараз $100 \%$ електроенергії в Нижній Австрії, найбільшій федеральній землі країни, генерується з ВДЕ, а саме, $63 \%$ - на ГЕС, $26 \%$ - на ВЕС, $9 \%-3$ біомаси і $2 \%$ - за рахунок сонячної енергії. Що стосується Австрії в цілому, відновлювані джерела забезпечують 75 \% всього обсягу виробництва електроенергії.

\section{Швеція}

Розвиток енергетики в Швеції керується Законом про інтегровану кліматичну та енергетичну стратегію (2008 р.), яким встановлено ряд доволі амбітних цілей [3]. Зокрема, планується досягти 50 \% ВДЕ У валовому кінцевому споживанні енергії до 2020 р., відмовитися від викопних палив в транспортному секторі до 2030 р. й досягти повної декарбонізації до 2050 року. Тут і далі «повна декарбонізація» або «100\% скорочення викидів парникових газів» означає, що викиди парникових газів від людської діяльності не мають перевищувати їх поглинання екосистемами.

Також у 2015 році урядом Швеції було прийнято за мету стати першою країною, яка повністю відмовиться від викопного палива (без зазначення конкретного терміну досягнення мети), але при цьому залишається використання атомної енергії в певному обсязі. Для реалізації плану по відмові від викопного палива виділено значні кошти на впровадження цілої низки заходів, зокрема, на розвиток сонячної електрогенерації, дослідження технологій зберігання електроенергії, створення «розумних» мереж, модернізацію житлових будівель та підвищення ïx енергоефективності, впровадження ВДЕ на транспорті.

Ядерна енергетика залишається спірним питанням в країні, політика уряду в цьому секторі періодично зазнає змін. У 2010 році шведський парламент скасував закон про поетапну відмову від ядерної енергії. Продовжено перехідний період, протягом якого атомна енергія буде використовуватись, але будівництво нових реакторів буде дозволено лише на існуючих ділянках в разі необхідності заміни старих реакторів. Також було посилено контроль і нагляд за діяльністю атомних електростанцій.

\section{німеччина}

Енергетична Стратегія Німеччини до 2050 року (прийнята у 2010 р.) передбачає по- 
вну відмову від використання атомної енергії до 2022 року. Цей строк (коротший за попередньо прийнятий) було встановлено після аварії на японській AEC Fukushima Daiichi у березні 2011 року. Реалізація даного плану почалася із зупинки 8 найстаріших АЕС Німеччини. Відновлювані джерела енергії було визначено енергетичною стратегією як основною складовою структу ри енергопостачання країни у перспективі до 2050 року. Також було розроблено законодавчі механізми стимулювання розвитку ВДЕ та підвищення енергоефективності. Ці механізми (загалом 7) прописані у програмі «Енергетичний перехід» (Energiewende) [4].

Основні цілі Енергетичної Стратегії Німеччини до 2050 р. представлено в таблиці 1. Закон про відновлювані джерела енергії 2012 року (EEG 2012) визнав ці цілі обов'язковими. У 2050 році внесок ВДЕ до загального кінцевого енергоспоживання має становити $60 \%$, до споживання електроенергії - 80 \%. При цьому загальне споживання первинної енергії зменшиться на $20 \%$ до 2020 р. та на $50 \%$ до 2050 р. від рівня 2008 р.

Зазначені цілі видаються дуже серйозними,

Табл. 1. Основні показники Енергетичної Стратегії Німеччини до 2050 року [4]

\begin{tabular}{|c|c|c|c|c|c|}
\hline Показники & 2012 & 2020 & 2030 & 2040 & 2050 \\
\hline $\begin{array}{c}\text { Частка ВДЕ у } \\
\text { загальному кінцевому } \\
\text { споживанні енергіі }\end{array}$ & $10 \%$ & $18 \%$ & $30 \%$ & $45 \%$ & $60 \%$ \\
\hline $\begin{array}{c}\text { Частка ВДЕ у споживанні } \\
\text { електроенергії }\end{array}$ & $20 \%$ & $35 \%$ & $50 \%$ & $65 \%$ & $80 \%$ \\
\hline $\begin{array}{c}\text { Скорочення споживання } \\
\text { первинної енергії } \\
\text { (порівняно з 2008 р.) }\end{array}$ & $-5 \%$ & $-20 \%$ & $-30 \%$ & $-40 \%$ & $-50 \%$ \\
\hline $\begin{array}{c}\text { Скорочення споживання } \\
\text { електроенергії } \\
\text { (порівняно з 2008 р.) }\end{array}$ & $-1 \%$ & $-10 \%$ & Н.д. & Н.Д. & $-25 \%$ \\
\hline $\begin{array}{c}\text { Скорочення кінцевого } \\
\text { енергоспоживання }\end{array}$ & н.д. & $-10 \%$ & Н.д. & Н.д. & $-40 \%$ \\
\hline $\begin{array}{c}\text { на транспорті (порівняно з 2008 р.) } \\
\text { Скорочення викидів парникових газів } \\
\text { (порівняно з 1990 р.) }\end{array}$ & $-27 \%$ & $-40 \%$ & $-55 \%$ & $-70 \%$ & $-80 \%$ \\
\hline
\end{tabular}

н.д. - немає даних

i їх досягнення, окрім іншого, потребуватиме значного підвищення енергоефективності. На сьогодні вже досягнуто певний прогрес у виконанні цілей Енергетичної Стратегії Німеччини до 2050 року: частка ВДЕ в кінцевому енергоспоживанні збільшилася до 12 \% (дані 2013 р.), у споживанні електроенергії - до 28 \% (дані 2014 р.).

\section{CШ}

У 2014 році Президент США Барак Обама запропонував так звану «Всеосяжну Енергетичну
Стратегію» [5]. Одним з ії ключових елементів $\epsilon$ розвиток відновлюваних джерел енергії, переважно «зеленої» електрогенерації. Зокрема, планується майже потроїти обсяг виробництва електроенергії з ВДЕ - до 20 \% у 2030 році (без врахування гідроенергіï). При цьому викиди парникових газів на електростанціях США мають зменшитись на 32 \% до 2030 р. Треба зазначити, що окремі штати, наприклад, Каліфорнія, впевнено рухаються по шляху досягнення $100 \%$ енергії з відновлюваних джерел. 


\section{Каліфорнія}

Фахівцями Стенфордського Університету було проведено дослідження та аналіз майбутнього розвитку енергетики штату Каліфорнія. Основна ідея полягала у відмові від викопного палива та ядерної енергетики на користь відновлюваних джерел енергії. Шляхом нарощування нових потужностей на ВДЕ, впровадження заходів з підвищення енергоефективності та переходу з технологій генерації енергії, що використовують процеси горіння палива, на енергетику без використання будь-яких видів палива штат може досягти 100 \% відновлюваної енергетики та повністю відмовитися від викопного палива до 2050 року. При цьому прогнозується наступний внесок різних ВДЕ: сонячна енергія - 55\%, енергія вітру - $35 \%$, геотермальна енергія - $5 \%$, гідроенергія - 4 \%, енергія хвиль - 1 \%. Цікавим результатом даного дослідження $є$ також те, що площа земель, необхідних для встановлення всього запланованого обладнання на ВДЕ, займатиме лише 4,77 \% від загальної площі Каліфорнії. Очікуваний розподіл площі такий: ВЕС (наземні) $-2,77 \%$, ВEC (офшорні) - 0,86 \%, CEC - 1,14\%, геотермальні установки - 0,006 \% [6].

Існуюча динаміка розвитку відновлюваної енергетики в Каліфорнії свідчить про те, що штат успішно рухається у прогнозованому в дослідженні напрямку. Підтвердженням цього $€$ також офіційні заяви світових компаній, які мають свої штаб-квартири в даному регіоні, про перехід на відновлювану енергетику найближчим часом.

\section{Гаваї}

Влітку 2015 року Гаваї стали першим штатом США, який прийняв законодавчо закріплену мету - досягти 100 \% виробництва електроенергії з ВДЕ до 2045 року. Для контролю динаміки досягнення цієї мети законом також встановлено дві проміжні цілі: 30 \% «зеленої» електроенергії у 2020 р. та $70 \%$ - у 2040 р. Треба зазначити, що за останні п'ять років частка ВДЕ у виробництві електроенергії на Гаваях подвоїлася і складає наразі 22 \% загального обсягу. В разі невиконання офіційних цілей з розвитку «зеленої» електрогенерації енергокомпанії будуть вимушені сплачувати штраф у розмірі 2 цента за кожну «надлишкову» кіловат-годину, вироблену з викопних палив.

Фахівці організації Blue Planet Foundation, які брали участь у розробці закону штату щодо розвитку електрогенерації з ВДЕ, вважають, що Гаваї мають всі можливості досягти $100 \%$ «зеленої» електроенергії вже у 2030 році.

\section{Китай}

Наразі Китай $є$ одним 3 найкрупніших інвесторів в секторі відновлюваної енергетики в світі. Кошти, виділені державою на розвиток «зеленої» енергетики у період 2011...2015 pp., складали 473 млрд. доларів США. В результаті цього протягом останніх п'яти років в країні спостерігався стрімкий ріст електричних потужностей на ВДЕ, зокрема вітрових та сонячних електростанцій. У 2013 році завдяки впровадженню 13 ГВт сонячних фотоелектричних елементів обсяг уведення нових потужностей на ВДЕ вперше перевищив обсяг нових потужностей на викопних паливах.

Міжнародне енергетичне агентство зробило прогноз розвитку світової енергетики, згідно якому Китай може досягти більше 960 ГВт на ВДЕ до 2040 року й задовольнити за рахунок них майже 30 \% своєї потреби в електроенергії. Згідно іншого дослідження, виконаного Національним центром 3 відновлюваної енергетики Китаю у 2015 році, країна може покрити 85 \% загального виробництва електроенергії та 60 \% споживання первинної енергії за рахунок ВДЕ до 2050 року $[7,8]$.

\section{Індія}

Уряд Індії планує прийняти нову програму розвитку відновлюваної енергетики. Основною метою цієї програми буде досягнення 40 \% встановленої електричної потужності на ВДЕ у 2030 році. Це відповідатиме загалом близько 350 ГВт, в тому числі 250 ГВт сонячних електростанцій та 100 ГВт вітрових електростанцій. Наразі в Індії працюють 36 ГВт електричної потужності на ВДЕ, що складає приблизно 13 \% від загальної встановленої потужності [9].

Зведена інформація щодо ключових показників довгострокових енергетичних стратегій деяких країн ЄС та світу представлена в таблиці 2.

\section{Аналіз ситуації в Україні}


Табл. 2. Частка ВДЕ у валовому кінцевому енергоспоживанні деяких країн світу згідно даних їх офіційних енергетичних стратегій

\begin{tabular}{|c|c|c|c|c|c|}
\hline Країна & 2014 & 2020 & 2030 & 2040 & 2050 \\
\hline Австрія & $\begin{array}{c}30 \% \\
75 \%{ }^{1)}(y 2015)\end{array}$ & $\begin{array}{c}34 \% \\
16 \% \%^{4)}(1990) \\
17 \%^{5)}(2005)\end{array}$ & н.д. & н.д. & н.д. \\
\hline Данія & $\begin{array}{c}25 \% \\
20 \% \%^{5}(2005)\end{array}$ & $33 \%$ & $55 \%$ & $68 \%$ & $100 \%$ \\
\hline Німеччина & $\begin{array}{c}12,4 \%(\text { y } 2013) \\
27 \% \%^{4)}(1990) \\
9 \%^{5)}(2008)\end{array}$ & $\begin{array}{c}18 \% \\
40 \% \%^{4)}(1990) \\
20 \%^{5)}(2008)\end{array}$ & $\begin{array}{c}30 \% \\
55 \% \%^{4)}(1990) \\
30 \%{ }^{5)}(2008)\end{array}$ & $\begin{array}{c}45 \% \\
70 \%{ }^{4)}(1990) \\
40 \%{ }^{5)}(2008)\end{array}$ & $\begin{array}{c}60 \% \\
\left.80 \%^{4}\right)(1990) \\
50 \%^{5)}(2008)\end{array}$ \\
\hline Швеція & $52,1 \%$ (у 2013) & $\begin{array}{c}50 \% \\
40 \%^{4)}(1990) \\
20 \% \%^{5)}(2008)\end{array}$ & $100 \%{ }^{3)}$ & н.д. & $100 \% \%^{4)}$ \\
\hline Швейцарія & $17,5 \%$ (у 2010) & $\begin{array}{r}45 \% \\
16 \%{ }^{5)}\end{array}$ & н.д. & $\begin{array}{r}56 \%(\text { y } 2035) \\
45 \%(\text { y } 2035)\end{array}$ & $60 \%$ \\
\hline Індія & $13 \%{ }^{1)}(y 2015)$ & н.д. & $\begin{array}{c}40 \%^{2)} \\
33 \ldots 35 \%{ }^{4)}\end{array}$ & н.д. & н.д. \\
\hline США (Гаваї) & $20 \%$ & $30 \%$ & $40 \%$ & $70 \%$ & $100 \%(y ~ 2045)$ \\
\hline Коста-Рика & $\begin{array}{c}95 \ldots 99 \% \\
100 \%(y)(y)\end{array}$ & $100 \%{ }^{4)}(y-2021)$ & н.д. & н.д. & н.д. \\
\hline $\begin{array}{l}\text { Саудівська } \\
\text { Аравія }\end{array}$ & $1 \%(y 2015)$ & н.д. & н.д. & $100 \%$ & н.д. \\
\hline Уругвай & $\begin{array}{c}55 \%(\mathrm{y} 2015) \\
94,5 \%^{1)}(\mathrm{y} 2015)\end{array}$ & $\begin{array}{c}88 \% \%^{4)} \\
(y 2017,2009 \ldots 2013)\end{array}$ & $100 \%{ }^{4)}$ & н.д. & н.д. \\
\hline
\end{tabular}

Примітка: в дужках вказано рік порівняння або досягнення показника

1) У виробництві електроенергї.

2) Частка електрогенеруючих потужностей на ВДЕ.

3) У транспортному секторі.

4) Скорочення викидів парникових газів.

5) Підвищення рівня енергоефективності.

Згідно даних енергетичного балансу України за 2014 рік [10], частка ВДЕ у загальному постачанні первинної енергії становить 2,6 \%, в тому числі біомаса - 1,8 \% (1,93 млн. т н.е.). Національним планом дій 3 відновлюваної енергетики до 2020 року [11] поставлено за мету досягти 11 \% ВДЕ у валовому кінцевому енергоспоживанні у 2020 році, що відповідає зобов'язанням України, прийнятим перед Енергетичним Співтовариством.

Наразі в Україні $є$ чинною Енергетич- на Стратегія на період до 2030 року [12], яка була прийнята у липні 2013 р. і відразу піддана обгрунтованій критиці. Основні показники цього документу жодним чином не узгоджуються 3 НПДВЕ. Стратегія (базовий сценарій) передбачає зростання споживання енергоресурсів на $25 \%$ у 2030 р. (238,1 млн. т у.п.) порівняно 3 базовим 2010 р. В тому числі заплановано суттєве збільшення споживання електроенергії - на 55 \% у 2030 р. порівняно з 2010 р. Такі прогнози видаються хибними, бо вони не спрямовані на 
заощадження паливно-енергетичних ресурсів та підвищення енергоефективності. Також у діючій Енергетичній Стратегії майже не поставлено конкретних цілей з розвитку ВДЕ - не зазначено частку відновлюваних джерел енергії у валовому кінцевому енергоспоживанні, яка має бути досягнута у 2020 р. А ті цифри щодо ВДЕ, які все ж наведено, видаються необгрунтовано заниженими.

3 метою виправлення цієї ситуації на сьогодні в Україні вже розроблено два проекти нового документу - Енергетичної Стратегії на період до
2035 року.

Перший проект Стратегії підготовлено Національним інститутом стратегічних досліджень [13]. Даним документом заплановано досягнення частки ВДЕ у валовому кінцевому енергоспоживанні $11 \%$ у 2020 р. та $20 \%$ у 2035 році. При цьому внесок відновлюваних джерел в загальне виробництво електроенергії становитиме $13 \%$ у 2020 р. та $18 \%$ у 2035 р. (табл. 3). Ці цифри узгоджуються з показниками НПДВЕ, що $\epsilon$ позитивною стороною документу.

Проте даний проект Енергетичної Стратегії

Табл. 3. Основні показники проекту Енергетичної стратегії України на період до 2035 року (варіант, підготовлений Національним інститутом стратегічних досліджень) [13]

\begin{tabular}{|l|c|c|c|c|c|}
\hline Показники & 2013 & 2020 & 2025 & 2030 & 2035 \\
\hline $\begin{array}{l}\text { Споживання ПЕР (енергетичне використання), } \\
\text { млн. т н.е., }\end{array}$ & 110,62 & 114,4 & 117,6 & 121,4 & 126,1 \\
\hline \multicolumn{1}{|c|}{ - зокрема ВДЕ } & 3,13 & 9,6 & 13,3 & 17,3 & 19,5 \\
\hline Частка ВДЕ у споживанні первинних ресурсів & $2,7 \%$ & $8,4 \%$ & $11,4 \%$ & $14,2 \%$ & $15,5 \%$ \\
\hline Кінцеве енергоспоживання, млн. т н.е. ${ }^{1)}$ & 69,6 & 77,9 & 80,8 & 85,1 & 88,9 \\
\hline Частка ВДЕ в валовому кінцевому енергоспоживанні & $4,5 \%$ & $12,3 \%$ & $16,5 \%$ & $20,3 \%$ & $21,9 \%$ \\
\hline Кінцеве енергоспоживання, млн. т н.е. ${ }^{2)}$ & 86,6 & 86,9 & 89,1 & 93,5 & 97,5 \\
\hline Частка ВДЕ в валовому кінцевому енергоспоживанні & $3,6 \%$ & $11,0 \%$ & $15,0 \%$ & $18,5 \%$ & $20,0 \%$ \\
\hline Виробництво електроенергії, ТВт.год, & 194,4 & 209,46 & 232,97 & 258,24 & 276,62 \\
\hline \multicolumn{1}{|c|}{ - зокрема з ВДЕ } & $\sim 15,7$ & 28,12 & 38,44 & 47,60 & 50,1 \\
\hline Частка ВДЕ у виробництві електроенергії & $\sim 8,1 \%$ & $13,4 \%$ & $16,5 \%$ & $18,4 \%$ & $18,1 \%$ \\
\hline
\end{tabular}

1) Згідно енергетичних балансів.

2) Згідно вимог Директиви 2009/28/EC.

передбачає зростання валового кінцевого енергоспоживання України на 12,6 \% у 2035 р. порівняно з 2013 р., що суперечить загальній тенденції СС, спрямованій на скорочення загального споживання енергії та підвищення енергоефективності. Хоча в документі зазначено конкретні цілі 3 підвищення ефективності використання ПЕР, видається, що їх недостатньо для підтримання обсягу споживання енергоресурсів хоча б на поточному рівні. Справедливості заради треба відмітити, що в НПДВЕ також прогнозується збільшення ВКЕ на 15,5 \% у 2020 р. порівняно 3 2014 р. згідно базового сценарію та на 9\% згідно енергоефективного сценарію.

Другий варіант проекту Енергетичної
Стратегії до 2035 року, Нову Енергетичну стратегію України, було розроблено Центром Разумкова разом $з$ іншими провідними неурядовими громадськими організаціями та науководослідними закладами України [14].

На відміну від першого проекту енергетичної стратегії України до 2035 р. та від діючої редакції енергетичної стратегії України до 2030 р., проект HEC планує скорочення споживання первинних енергоресурсів 3 115,2 млн. т н.е. в 2013 р. до 102,6 млн. т н.е. в 2035 р. Це створює правильні орієнтири для розвитку енергозбереження й енергоефективних технологій і $є$ сильною стороною даного документу. Проте цілі з розвитку ВДЕ на 2020 р. не відповідають зобов'язанням 
України, прийнятим перед Енергетичним Співтовариством та закріпленим у НПДВЕ (11 \% ВДЕ у валовому кінцевому споживанні енергії до 2020 р.). В проекті ж Нової Енергетичної стратегії планується досягнення «понад $7 \%$ » ВДЕ в кінцевому споживанні енергії до 2020 p. (c. 10), хоча пізніше вже зазначений конкретний показник 8 \% (с. 86).

На 2035 р. НЕС ставить ціль 20 \% ВДЕ в загальному постачанні первинної енергії (с. 85) i, в той же час, 20 \% ВДЕ у валовому кінцевому споживанні енергії (с. 86). Ці цілі суперечать одна одній. Робиться заява, що «зростання виробництва енергії з ВДЕ відбуватиметься за рахунок розвитку альтернативної енергетики в Україні (більш ніж на $60 \%$ за рахунок біопалива)» (с. 29). Прогноз правильний й відповідає тенденціям і статистиці розвитку ВДЕ в СС та світі, проте пізніше (с. 85) зазначається, що частка біоенергетики складатиме лише 39 \% від усіх ВДЕ. Це суперечить попереднім заявам і невиправдано занижує вклад біоенергетики по відношенню до інших ВДЕ.

\section{Енергоефективність}

В листопаді 2015 року в Україні було прийнято Національний план дій з енергоефективності на період до 2020 року (Розпорядження КМУ № 1228-р від 25.11.2015) [15]. Планом передбачено досягнення у 2020 році національної індикативної мети з енергозбереження в обсязі $9 \%$ від середнього показника кінцевого енергоспоживання за період 2005...2009 pp., що еквівалентне 6,5 млн. т н.е. Крім того, Національний план дій визначає проміжну мету до 2017 року скоротити енергоспоживання на 5 \%. Досягти цих показників планується шляхом реалізації заходів у чотирьох основних секторах кінцевого споживання енергії - побутовому секторі (де очікується найбільший ефект), секторі послуг, у промисловості та на транспорті.

\section{Скорочення викидів парникових газів}

Як сторона Рамкової Конвенції ООН про зміну клімату та Кіотського протоколу, на Паризькій конференції сторін у грудні 2015 року Україна окреслила наступний Очікуваний національно-визначений внесок до скорочення викидів парникових газів: у 2030 році обсяг викидів має не перевищувати 60 \% рівня 1990 року, тобто бути не більше 566 млн. т $\mathrm{CO}_{2 \mathrm{e}}$ /рік. Але по факту це означає, що замість зменшення викидів вуглецю в атмосферу планується їх збільшення, оскільки вже у 2012 р. обсяг викидів парникових газів в країні складав 402 млн. т $\mathrm{CO}_{2 \mathrm{e}}$. Ряд громадських організацій (Фонд зелених інвестицій, Національний екологічний центр України) та фахівців висловили своє непогодження 3 такою офіційною позицією й звернулися до уряду 3 пропозицією розглянути інший сценарій, який не передбачає фактичного збільшення викидів парникових газів в Україні.

\section{Висновки}

Наразі все більше країн світу ставлять собі за мету перехід на 50 і більше відсотків використання відновлюваних джерел енергії в енергетичному секторі. Кожна 3 цих країн розробила свій власний шлях досягнення мети, який відрізняється від інших часом імплементації, об'ємом, цільовими напрямками. Це пов'язано як 3 необхідністю підвищення рівня енергетичної безпеки, так і з задачею недопущення глобальної зміни клімату шляхом скорочення викидів вуглецю в атмосферу. Іншою тенденцією сьогодення $\epsilon$ усвідомлення необхідності широкого впровадження енергоефективних заходів і включення їх до енергетичних стратегій. Таким чином, незалежність від традиційних палив досягається двома шляхами - впровадженням відновлюваних джерел енергії та скороченням загального енергоспоживання.

Для прискорення розвитку «зеленої» енергетики в Україні та підвищення рівня енергоефективності вважаємо за необхідне:

- Доопрацювати та прийняти Енергетичну Стратегію України на період щонайменше до 2035 року з амбітнішими цілями щодо відновлюваних джерел енергії та енергоефективності.

- Прийняти адекватні національні цілі зі скорочення викидів парникових газів і послідовно виконувати їх.

- У довгостроковій перспективі (до 2050 р.) намагатись брати приклад 3 країн світу та Європи, що ставлять собі високі цілі (50\% і більше) щодо переходу на ВДЕ, скороченню викидів парникових газів та підвищенню рівня енергоефективності. 
- На національному рівні сприяти тому, щоб клімат планети розвивався за сценарієм 2DS (підвищення середньорічної температури на 2 градуси до 2050 року).

\section{ЛІТЕРАТУРА}

1. Energy Strategy 2050 - from coal, oil and gas to green energy (Denmark), 2011. http://www. efkm.dk/sites/kebmin.dk/files/news/from-coal-oiland-gas-to-green-energy/Energy $\% 20$ Strategy $\% 20$ 2050\%20web.pdf

2. Jurrien Westerhof. Geschäftsführer Erneuerbare Energie Österreich. http://www.ots. at/presseaussendung/OTS_20150928_OTS0027/ erneuerbare-energie-oesterreich-schlaegteckpunkte-fuer-energiestrategie-vor

3. Energy Policies of IEA Countries. Sweden. 2013 Review. IEA, 2013. http://www.iea.org/ textbase/nppdf/free/2013/sweden2013 excerpt.pdf

4. Energy Policies of IEA Countries. Germany. 2013 Review. https://www.iea.org/publications/ freepublications/publication/Germany2013_free.pdf

5. The All-of-the-above Energy Strategy (USA). https://www.whitehouse.gov/sites/ default/files/docs/clean_energy_record.pdf

6. Brian Merchant. California Will Run on 100 Percent Clean Energy by 2050, Stanford Professor Says. http://motherboard.vice.com/read/californiawill-run-on-100-percent-clean-energy-by-2050stanford-professor-says

7. Energy Snapshot of the Week. IEA, 2015. http://www.iea.org/newsroomandevents/ graphics/20150909-china-electricity-generation-bysource-and-co2-intensity.html

8. China 2050 high renewable energy penetration scenario and roadmap study. Energy Research Institute, National Development and Reform Commission, 2015. http://www.efchina.org/ Attachments/Report/report-20150420/China-2050High-Renewable-Energy-Penetration-Scenario-andRoadmap-Study-Brochure.pdf

9. Smiti Mittal. India Aims For 350 GW Renewable Energy Capacity By 2030. http:// cleantechnica.com/2015/09/23/india-aims-350-gwrenewable-energy-capacity-2030/

10. Енергетичний баланс Украӥни за 2014 рік. Експрес-випуск Державної служби статистики України від 21.12.2015 № 562/0/08.4.2вн-15.

\section{1. Постанова КМУ № 902-р від 01.10.2104} «Про Національний план дій 3 відновлюваної енергетики на пері-од до 2020 року». http:// zakon4.rada.gov.ua/laws/show/902-2014-\%D1\%80

12. Енергетична стратегія Украӥни на період до 2030 року. Схвалена Розпорядженням КМУ №1071 від 24.07.2013. http://zakon5.rada.gov.ua/ laws/show/n0002120-13/paran3\#n3

13. Фінальний варіант проекту Енергетичної стратегї України на період до 2035 року, 09.06.2015. http://mpe.kmu.gov.ua/minugol/control/ $\mathrm{uk} /$ doccatalog/list?currDir $=50358$

14. Нова Енергетична стратегія України: безпека, енергоефективність, конкуренція, 07.08.2015. http://mpe.kmu.gov.ua/minugol/control/ uk/doccatalog/list? currDir $=50358$

15. Розпорядження КМУ № 1228-р від 25.11.2015 «Про Національний план дій 3 енергоефективності на період до 2020 року». http://www.kmu.gov.ua/control/ru/ cardnpd?docid=248668419 
ANALYSIS OF ENERGY STRATEGIES OF EU AND WORLD COUNTRIES AND THE ROLE OF RENEWABLES IN THE STRATEGIES. PART 2

\section{Geletukha G.G., Zheliezna T.A., Bashtovyi A.I.}

Institute of Engineering Thermophysics of the National Academy of Sciences of Ukraine, vul. Zhelyabova, 2a, Kyiv, 03680, Ukraine

The paper covers state of the art and prospects for the development of renewable energy in a number of EU and world countries including Ukraine. Available energy strategies and forecasts for the energy sector development until 2050 are analyzed. It is shown that the threat of global warming, the fact that fossil fuels are exhaustible and other challenges of the present time force countries to change the structure of energy sector significantly. Now one can observe two basic tendencies, namely replacement of fossil fuels by renewables and reduction of energy consumption at the expense of introduction of energy efficient technologies and energy saving measures. More and more countries are developing and implementing their plans and strategies for considerable, up to $50 \ldots 100 \%$, covering energy demand at the expense of renewable energy sources. At the same time, they act appropriately on reducing consumption of primary energy.

References 10, tables 3

Key words: renewable energy sources, renewable energy, final energy consumption, energy efficiency, greenhouse gases

1. Energy Strategy 2050 - from coal, oil and gas to green energy (Denmark), 2011. http://www. efkm.dk/sites/kebmin.dk/files/news/from-coal-oiland-gas-to-green-energy/Energy $\% 20$ Strategy $\% 20$ 2050\%20web.pdf

2. Jurrien Westerhof. Geschäftsführer Erneuerbare Energie Österreich. http://www.ots. at/pressaussendung/OTS_20150928_OTS0027/ erneuerbare-energie-oesterreich-schlaegteckpunkte-fuer-energiestrategie-vor

3. Energy Policies of IEA Countries. Sweden. 2013 Review. IEA, 2013. http://www.iea.org/ textbase/nppdf/free/2013/sweden2013 excerpt.pdf

4. Energy Policies of IEA Countries. Germany. 2013 Review. https://www.iea.org/publications/ freepublications/publication/Germany2013_free.pdf

5. The All-of-the-above Energy Strategy (USA https://www.whitehouse.gov/sites/default/files/docs/ clean_energy_record.pdf

6. Brian Merchant. California Will Run on 100 Percent Clean Energy by 2050, Stanford Professor Says. http://motherboard.vice.com/read/californiawill-run-on-100-percent-clean-energy-by-2050stanford-professor-says

7. Energy Snapshot of the Week. IEA, 2015. http://www.iea.org/newsroomandevents/ graphics/20150909-china-electricity-generation-bysource-and-co2-intensity.html

8. China 2050 high renewable energy penetration scenario and roadmap study. Energy Research Institute, National Development and Reform Commission, 2015. htt p://w w w. efchina.org/Attachments/Report/report-20150420/ China-2050-High-Renewable-Energy-PenetrationScenario-and-Roadmap-Study-Brochure.pdf

9. Smiti Mittal. India Aims For 350 GW Renewable Energy Capacity By 2030. htt p : // cleantechnica.com/2015/09/23/india-aims-350-gwrenewable-energy-capacity-2030/

10. Energy balance of Ukraine 2013. Expressissue by the State Statistics Service of Ukraine № $562 / 0 / 08.4 .2 \mathrm{BH}-15$ of 21.12 .2015 .

11. CMU's Resolution № 902-p of 01.10.2104 «On the National Renewable Energy Action Plan until 2020» http://zakon4.rada.gov.ua/laws/ show/902-2014-\%D1\%80

12. Energy Strategy of Ukraine until 2030. Approved by CMU's Resolution № 1071 of 24.07.2013. http://zakon5.rada.gov.ua/laws/show/ n0002120-13/paran3\#n3

13. Final draft Energy Strategy of Ukraine until 2035, 09.06.2015. http://mpe.kmu.gov.ua/minugol/ control/uk/doccatalog/list?currDir $=50358$

14. New Energy Strategy of Ukraine: security, energy efficiency, competitiveness, 07.08.2015. http://mpe.kmu.gov.ua/minugol/ 
control/uk/doccatalog/list?currDir $=50358$

15. CMU's Resolution № 1228-p of 25.11.2015 "On the National Energy Efficiency Action Plan until 2020". http://www.kmu.gov.ua/control/ru/ cardnpd?docid $=248668419$

Получено 11.01.2016

Received 11.01.2016 